\title{
Wage Structures and Family Economies in the Catalan Textile Industry in an Age of Nascent Capitalism.
}

\section{Enriqueta Camps.}

June 2003

Key words: labour market, contracts, family strategies, state welfare.

Jel codes: C71 J21 J16 J31

\section{Area 04 Economic and Business History.}

\begin{abstract}
:
This paper deals with changes in managerial practices in Catalonia in an age of nascent capitalism (1830-1925) and adaptive family strategies in order to face the absence of state welfare. During the $19^{\text {th }}$ Century and in the absence of recorded labor contracts, human resources of the firm were organized by means of implicit contracts and informal labor markets. With the advent of scientific organization of labor, wage per hour worked began to be recorded. This is why in the 1920s the perfect competition model applies to our case. On the other hand, in the same period, and in the absence of state welfare, ideas stemming from cooperative game theory apply to the pattern of household income formation. Kin related networks were used to improve the living standards of the household. In this particular direction we also show that there was a demonstration effect by means of which migrant's living standards were higher than those of natives.
\end{abstract}




\title{
Wage structures and family economies in the Catalan textile industry in an age of nascent capitalism. ${ }^{1}$
}

\author{
Enriqueta Camps-Cura. \\ June 2003
}

Key words: labour market, contracts, family strategies, state welfare.

Jel codes: C71 J21 J16 J31

Area 04 Economic and Business History.

\begin{abstract}
:
This paper deals with changes in managerial practices in Catalonia in an age of nascent capitalism (1830-1925) and adaptive family strategies to face the absence of state welfare. During the $19^{\text {th }}$ Century and in the absence of recorded labour contracts, human resources of the firm were organized by means of implicit contracts and informal internal labour markets. With the advent of scientific organization of labour, wage per hour worked began to be recorded. This is why in the 1920s the perfect competition model applies to our case. On the other hand, in the same period, and in the absence of state welfare, ideas stemming from cooperative game theory apply to the pattern of household income formation. Kin related or no kin related networks were used to improve the living standards of the household. In this particular direction we also show that there was a demonstration effect by means of which migrants' strategies of co residence were imitated with delay by natives and therefore migrant's living standards were higher than those of natives.
\end{abstract}

\section{Introduction}

Recent research on both European and American societies has emphasised the significance of the relationship between the micro historical dynamics of working class household economies and major features of the labour market. ${ }^{2}$ The key issue is the extent to which individuals were in a position to decide for themselves when and in what way to participate in the labour market. The ratio between economically active and inactive members of the household, its size and structure and the type of economic activity all served to influence both workers' earnings and which members of the family entered the labour market. The impact of household dynamics on the composition of the workforce is even more apparent when focusing on those sections of the population, particularly women and children, whose employment is often not recorded in the census. ${ }^{3}$ Estimates of living standards fail to take account of the unregistered employment of women and children and can therefore be misleading ${ }^{4}$ but can be challenged by thorough analysis of family budgets. ${ }^{5}$ 
The aim of this essay is to document transformations of the labour market at regional level using micro historical datasets. This micro historical analysis has allowed us to build time series as well as cross section evidence on the transformation of the labour market during the second half of the nineteenth century and the first third of the twentieth century. The region under study is Catalonia, the only Spanish country that witnessed the formation of nascent industrial capitalism prior to 1830. During the eighteenth century economic specialisation took place within the region. According to Pierre Vilar's ${ }^{6}$ classic point of view, urban growth and agrarian specialisation in commercialised agriculture in the littoral led to increased consumption of woollen textiles of popular demand. These textiles were produced on a putting out basis and their employment expanded in the central part of the region and the Pyrenees. During the first decades of the $19^{\text {th }}$ century the loss of colonial markets, British industrial competition and the nature of the domestic market itself involved the mechanisation of the textiles industry and the transition to the factory system. ${ }^{7}$ And industrial investment was rooted in savings of emerging bourgeoisie of the region. But the absence of mineral resources and therefore the lack competitiveness in foreign markets prevented that industrial activities expanded in a greater extent. In this context the demand for labour with capital intensive technologies could just increase up to certain limits.

In the first part of the paper we will examine the practices adopted by management in order to determine wage levels in the Catalan labour market during industrialisation.

In this part we wish to ascertain whether the perfect competition model could apply to the labour market in a context in which we shall see no written contracts were witnessing the agreements between employers and employees. In the second part we shall see the transformations of the labour market during the early part of the second industrial revolution through a cross section analysis. Admittedly it is very difficult to quantify the nature of the regional labour market given the limitations of the sources that are available, but with care it is possible to examine for representative groups of textile workers the factors that governed the supply of labour by households and its application within the factories. Aggregation methodologies would be less enlightening to this end, although more representative in statistical terms. On the other hand the factory-based datasets we have built up for the $19^{\text {th }}$ century allow for a time series evidence, which, for the moment, it is impossible to do with aggregation data.

My last intention is to make a final reflection on how variations in the wages and the number of different members of the household reflected the absence in Spain in the late nineteenth and early twentieth centuries of a system of state welfare similar to that which was already in operation in Britain. For the latter it has been argued that its specific household formation patterns (small households restricted largely to couples and parents and unmarried children) were only made possible because of the financial assistance which the state provided to working families. ${ }^{8}$ My argument, it should be stressed, is wt that such assistance was unnecessary. However, I do wish to insist on the extent to which households were able to adapt their make-up in order to preserve their standard of living even when faced with an adverse economic situation.

The contextual evidence on industrial Catalonia in terms of wage structures and family economies and welfare is limited. Camps (1995) dealt for the first time with these topics by means of micro historical analysis of several middle sized industrial towns during the $19^{\text {th }}$ century. Topics on charity welfare and women's work in $18^{\text {th }}$ 
Century Barcelona were presented by the leading research by Carbonell $(1997)^{9}$. The new evidence from this article just tries to highlight new outcomes of research and implications for history and economic history. Nonetheless it should be pointed out that urban population was growing fast in the period under study and by 1900 people living in towns and cities of more than 10,000 inhabitants accounted for 40 per cent of total population. According to De Vries (1881) only England and Wales and Scotland had higher rates of urbanization. In the period under study in most of these towns, including Sabadell, migration accounted for in between 40 and 60 per cent of total population. In Barcelona by 190060 per cent of the population was born outside de province and therefore a higher rate outside the town. Therefore overall Catalan towns and cities were receiving and intense influx of migration that is similar to that observed in most urbanized regions of Britain ${ }^{10}$.

\section{The formation of the factory labour market in the nineteenth century}

The relatively higher wages available in the industrial urban areas of Catalonia was a major attraction for immigrants with woollen textile cottage workers constituting most of the first cohort of urban factory workers (Camps 1992). A second characteristic of the migration pattern, applicable to both industrial and agricultural areas of Spain in the nineteenth century, was that the majority of the migrants had already formed families which had reached a critical phase in their life cycle by the time they had settled permanently in an urban area. ${ }^{11}$ In the Catalan industrial case, migration involved movement from town to town before a permanent job was acquired in the textile coal powered mills in urban areas. ${ }^{12}$ The rapid adoption of capital intensive techniques in the period $1830-1860^{13}$ produced a slow and sustained rise in the demand for labour. Employers made substantial savings on their labour costs through increases in labour productivity. ${ }^{14}$ Figure 1 charts the trends in the numbers employed in the textile industry between 1830 and 1913 and indicates that over this period there had only a modest increase in the demand for labour. ${ }^{15}$

Figure 1 records total employment in the textiles according to gender and including children. We think that the aforementioned series, when systematically registering work of women and children in addition to male adults, offers an alternative view to that which provides us with the results of the official population censuses. Notice in this figure that the first pick in employment is 1850 when manual work was expanding and technological had been introduced in the spinning. Another result form the manual era is the high contribution by women. The pressure for demand of labour and its handicraft (domestic) organization made possible the high participation rates of married women. The decrease in textile employment in the 1850s and 1860s resulted from the transition from manual to mechanised work combined with the impact of the Civil War in North America ("cotton famine"), which was followed by a financial crisis. In reality the supply of labour exceeded temporarily the demand as a result of the contraction of employment caused by technological change and the high propension of Catalan population to proletarianize (Camps, 1994). The presence of mobile textile workers with families is evidence of an uneven labour market in which there was a plentiful supply of labour. Such a labour market obviously operated on the basis of cheap labour.

Insert Figure 1 about here 
Despite the high elasticity of the labour supply with respect to wages, we cannot apply the perfect competition ${ }^{16}$ model to this period because of two main factors: the nature of labour contracts and the process of qualification.

In the first place, starting with the nature of contracts, it should be highlighted that until the First World War, they were implicit, both in the literal sense of the word and in the sense attributed by the labour economy. ${ }^{17}$ And there is a fundamental reason why that was so: written contracts did not exist. In our context, the word "contract" is used in its purest sense: that of a mutual agreement between the worker and the company. Thus, we have proof that employers and workers reached a verbal agreement as to the retribution for the work done and what it consisted of and how it was organised. For example, the stages in the spinning process using the self-acting mule and weaving were organised in teams (that is to say, the team leader used subcontracted labour) and remunerated as piecework. Moreover, variable retribution was agreed to according to the team's productivity and the company pay roll shows the net income of the group. This latter point suggests that logically the man or woman that led the group and subcontracted labour gave their salary to their auxiliaries. Many jobs, due to their very nature, could not make use of factory economies of scale (corduroy finishing, piece workers, darner, launderers...) and were commissioned out to women living nearby to perform the at home. The working class aristocracy and foremen were, however, paid on a weekly or monthly basis. Blue collar workers and apprentices were paid per day worked. Such examples prove that in factories in the 19th century, different systems coexisted for the organisation of work and its remuneration. In short, as there were no written rules concerning the management of human resources, when workers were incorporated into a work post, their retribution and how it was organised had to be agreed to. Therefore, in the first large companies and prior to the scientific methods of organising work which did not exist until the end of the nineteenth century, it was difficult to establish homogeneous formulas for production management, ending up, as we shall see, falling to a great extent, on skilled workers. Bookkeeping difficulties in a labour regime based on verbal agreements and a variety of ways of organising and remunerating labour lead one to believe that the jb market was hardly one of perfect competition and was the root cause of the predominance of implicit contracts.

Implicit contracts also become apparent when we analyse the time series evolution of wages according to the age cohort presented in table $1^{18}$. For example, the critical determinant of future earnings was the time elapsed since commencement of employment by each cohort of workers as Table 1 makes clear. Table 1 has been complied by linking marriage registers with the employment records of one of the largest textile cotton factories in the Iberian peninsula., 'España Industrial S.A. in Barcelona (Sans). ${ }^{19}$ It is significant that members of later cohorts never obtained the earnings of the first cohort after 1869-1871 which saw a conclusion to the firm's growth before major restructuring occurred between 1887 and 1890 . The wage differentials experienced by the first cohort after 1870 suggests again that it is appropriate to consider implicit contracts as in force at this time. ${ }^{20}$ Certain members of the first cohort were regarded with higher wages, which were not offered to bettertrained later cohorts. This pattern of earnings departs from that which would be expected had perfect competition applied. It also differs from nature of the relationship between wages and length of service in late twentieth century workers for which it has been observed that younger cohorts had an steeper slope of their 
longitudinal income evolution than the most senior. Longitudinal evidence of Table1 shows instead that the highest rate of increase of income was obtained by the most senior cohorts in our $19^{\text {th }}$ century context. In this respect 'España Industrial, S.A.' seems typical of much of Catalan industry in the nineteenth century, as portrayed in the trade union press. In 1892, in the aftermath of a strike, the trade unions claimed 'in the event additional labour is required, follow custom and preference the most senior or, should fewer hands be needed, fire the most recent (workers)'. ${ }^{21}$ Other practices resulted in the adaptation to the factory system of the artisanal conventions of promotion and training which in turn yielded a system of labour allocation that resembled in some ways modern internal labour markets. ${ }^{22}$

Insert Table 1 about here

In a labour market composed of cheap and abundant labour, implicit contracts and informal labour markets seem to have minimised the managerial transaction costs. Figure 2 and table 1 detail wages according to seniority and years of service, based on the analysis of payments made to individual employees while employed by España Industrial, S.A.

We focus first on the length of the contracts of skilled senior workers. The vital role played by senior artisans in every day management of labour and production guaranteed that their contracts were long: 7 years in average. Their promotional prospects, degree of skill and the organisational bases of the factory guaranteed that they became crucial for the smooth running of the firm. Senior artisans undertook provided training and organised their work teams in the factory. ${ }^{23}$ This explains why their wages increased in line with their length of service. The wage of unskilled workers also increases along with years of service since these workers were in fact apprentices. By contrast, foremen, despite their position at the top of the wage hierarchy, did not see their wages rise with the passage of time. Most of these foremen had migrated to Barcelona from Alsace and were older than most other employees at the time they joined the firm. For a managerial role, they needed language skills in order to discipline and motivate the workers. Their primary function was to make feasible the transmission of new technology. In addition, they were probably recruited to ensure an orderly process of labour recruitment. The failure of their wages to rise with the length of their service can only properly be understood when we bear in mind that the most experienced artisans performed most of the managerial tasks. It was only after the 1890s that training institutions within Catalonia were in a position to supply the middle-ranking and upper technicians to supervise production and the management of labour. From this point we shall see labour markets were modernised, the relationship between seniority and the wage paid was modified and the managerial revolution transformed the internal job market. This was the experience of 'España Industrial, S.A.' during the 1890s. Only later did these patterns spread to other Catalan factories. After 1919, with the diffusion of scientific labour organisation, wages and labour procedures were standardised and the labour practices pointed out till now became obsolete.

Insert Figure 2 at about here 
One of the legacies for the economic historian of Primo de Ribera's Dictatorship during the 1920s is the information he demanded on the social and economic characteristics of the population. Municipal archives across Spain contain, for the year 1925, the Municipal Censuses of Population that include both economic and demographic data. ${ }^{24}$ For the town of Sabadell, detailed information on the economic activity and income of every member of the household has been preserved. The municipal Census of 1925 can also fill some of the gaps in the 1920 returns. The nominal record linkage of the Labour Census of 1919 with the Municipal Census of 1920 revealed that approximately 30 percent of the employed population were missing from the 1920 Municipal Census. Nevertheless, this absent population was recorded in 1925 and their residence patterns uncover some of the strategies families adopted to maintain their standard of living. For Sabadell, all three sources, the Labour Census of 1919, the Municipal Census of 1920 and Municipal Census of 1925 have been linked. This town provides an interesting case study of migrant waged workers as is evident from its rapid expansion (from 2,000 inhabitants in 1787 to 20,000 in 1887 and 45,000 in 1925). Most of the inhabitants were migrants themselves or had parents or grandparents who had migrated to Sabadell. They had nothing to inherit, whether they were first generation migrants or descendants of earlier migrants. There is evidence to show that most migrant urban households found it difficult to accumulate savings and lived at subsistence level. ${ }^{25}$ In other words, the family and household strategies that operated in the urban context were not influenced by other exogenous factors such as inheritance law and practice.

Evidence of the new patterns of labour allocation within the wage earning population is presented in Figures 3 and 4 for the employed population. Figures 3 and 4 are constructed by means of the calculation of the average age according to occupation and the corresponding average wage. Workers reporting a casual work and who declare no earnings are also included. In figures 3 and 4 we can notice that men and women undertook casual work at various ages and of different regional origin. Altogether such casual workers comprised in the 1920s some 20 percent of the economically active population when the Spanish economy was prospering and full employment could be anticipated. Nonetheless we must remember that Sabadell was specialised in the woollen textiles, and textiles in general did not take profit of the neutrality of Spain during World War I.

\section{Insert Figures 3 and 4 about here}

Figures 3 and 4 also make clear the relationship between age and income was very similar for natives, ${ }^{26}$ and migrants. This involves a sharp contrast with the situation in the nineteenth century when migrants and those born in prosperous industrial towns had different expectations of future income over their working lives as a result of the implicit contracts as discussed above. In the nineteenth century, members of the first cohort, the equivalents of the natives in Figures 3 and 4, had entered the factory labour market at a younger age than more recent immigrants and received higher wages (see Table 1 above). Admittedly, Figures 3 and 4, unlike Table 1, relies on cross-sectional not longitudinal data. The evidence though is sufficient to indicate the absence of any association in 1925 between length of service and the prospect of 
future earnings. Had there been such a relationship, immigrants who settled in the town later in life would have been less well paid over their life cycle than were natives. And this apply for men as well as for women. This proves that implicit contracts developed in an imperfectly competitive labour market during the nineteenth century were surmounted during the interwar period. On the one hand, capital accumulation, the development of a modern banking system, the use of electrical power and the creation of training institutions all helped to modernise the labour markets. On the other hand, the diffusion of the second industrial revolution and after 1919 the spread of scientific labour organisation which meant the written accountancy of hours worked and of the wage per hour, transformed the nature of labour contracts. In this new context in which labour contracts were recorded and the management of human resources on a modern bases was made plausible the labour market segmentations pointed in part 2 were logically removed. ${ }^{27}$ This pattern of identical income of migrants and natives is different to the one observed for overseas migration $^{28}$ form Northern Europe in which there was a gap of 15 years for migrants to reach the same income as natives. Nonetheless in this last case it is also observed that when the nature of training was identical wages were also identical. In our case migrations were mainly intraregional and therefore the process of training was similar for natives and migrants. With equal training when obstacles to free competition were removed the wages according the place of birth became the same. Another result form these figures in terms of life cycle is that after the age of 50 the income was declining for men. Therefore we can expect that this age is indicative of the beginnings of the third age. The third age threshold for women is also 50 years old. But women's participation rates after the age of 40 abruptly declined in opposition to those of men. Camps(1998).

By 1925 there had been an improvement in the economic condition of working married women relative to that of working men. Whilst it is true that during the eighteenth century most married working class women undertook paid work, they could earn as little as one twentieth of the wage of a senior artisan. ${ }^{29}$ In the nineteenth century the earnings of women remained stable as they aged and job contracts were short, ${ }^{30}$ evidence of another kind of labour market segmentation: one based on gender. By 1925 women could for the first time expect their wages to rise during at least part of their working life. One reason for this was that they could take advantage of long term job contracts and on-the-job training that were so typical of the large firms that emerged during the early twentieth century phase of the industrial revolution.

On the other hand, although research on other regions has documented the entry of married women into the labour market even before the Second World War, ${ }^{31}$ our results show only 20 percent of married women earning wages from factory work. Such a low rate of participation in the labour market demonstrates the short run effects of mandatory schooling and hence investment in human capital on the supply of labour. Mandatory schooling coupled with the fall in fertility during the demographic transition had the immediate effect of modifying the supply of family labour. The entry of married women into the paid labour market cannot be explained solely in terms of a reduction in the amount of time women devoted to housework and a more egalitarian approach to the employment of women. Another factor occasioning the entry of married women into the labour market was that one of the major supports of family economies in the nineteenth century, work by children ${ }^{32}$ lost some of its earlier importance. Not only did the birth rate fall abruptly but also larger 
numbers of children delayed their entry into the labour market, increasing the demand for additional income. In figure 3 we can also observe that the active life of women came to an end at the age of 40. If we bear in mind all works women had to perform a plausible conclusion is that by that age they were already old.

Nevertheless, higher rates of participation in the labour force by married women as compared with the situation in the nineteenth century ${ }^{33}$ and rising wages over part of their life courses, failed to meet all the consumption needs of their households. Additional sources of income were required, and these included contributions by women through migration and sub-letting accommodation to lodgers. To these issues we now turn.

By 1925 many urban households had become complex according to the data presented by Camps (1998) and reproduced in Figure 5. The nature of the complexity differed from that produced by impartible inheritance which governed the transmission of land in the region and typically involved the co-residence of a married son with his parents. By contrast, household complexity in Sabadell involved the presence in the household of collateral kin. The financial contribution to the household of unmarried relatives such as siblings and cousins replaced the income that children might otherwise have provided, depleted as a result of mandatory schooling and the demographic transition. What we want to emphasise here is that not only the perfect competition model applies to the labour market but also co-operative game theory applies to the formation of the household income. By co-operative game theory we imply the existence of a bargaining process among the members of the household that leads to the maximisation of the utilities of the individual and the group (household) as well. In the absence of welfare, in a situation of relatively cheap labour and the transformations of the activity ratios of the household caused by the fertility decline and mandatory schooling, other relatives provided to the household as much as the 25 per cent of the household income during the first stages of the formation cycle. Normally this collateral kin were also migrants and while providing incomes to the household they were making use of the already settled households facilities. As we have said, in a situation of scarcity of economic resources this process led to the improvement of the economic position of both collateral kin and of the other members of the household.

In a town in which population was mainly composed of migrants, in the absence of welfare they still need to attract other economically active persons into their households and find alternative sources of income. Children entered the workforce at a later age than in previous generations and there were fewer of them as fertility fell. In the nineteenth century, the situation was very different as we have already demonstrated in that the earnings of children were an important element of many family economies. ${ }^{34}$ By contrast families in Sabadell in the early twentieth century could take advantage of the abundant supply of labour and the elasticity in respect to wages. The absence of state welfare in combination with the cheap supply of labour made feasible the development of adaptive family strategies that activated kin networks.

We can also see how the average income of the household head sharply decreases after the age of 40. By then children had completed compulsory schooling and became the bases of the family economy. Despite the important contribution of 
collateral kin in the first stages of the household formation cycle, the latter diminution of the wage of adult males had as a result de incorporation of children in the labour force normally at the age of 15 . Therefore children were not only the main human asset to face the third age but their contribution to the household income helps to explain the adaptive family strategies just presented.

These results differ from those which reflect British experience. ${ }^{35}$ The evidence from Britain is that the sources of household income were naturally limited to members of the simple family household: couple and offspring. In these circumstances working families needed state welfare in order to maintain their standard of living. In the absence of state welfare, family economies in Catalonia appear to resemble other examples from continental Europe. The aforementioned distinctive forms of family agreements to improve the living standards seem to apply in other contexts. ${ }^{36}$ However, British family forms have recently been revisited, revealing higher degrees of complexity than previously reported. ${ }^{37}$

\section{Conclusion}

Our purpose above has been to establish how employer and family strategies responded to an elastic labour supply with respect to wage, in the absence of a welfare system that involved a significant transfer of resources from rich to poor. During the nineteenth century and in the absence of written labour contracts large firms minimised their labour transaction costs through the adoption of implicit contracts and informal internal labour markets. After 1919 with the spread of scientific organisation of labour, the agreements between employer and employee were standardised and recorded in detail. With the availability of written contracts labour markets modernised and wage and labour prospects became homogeneous for all workers in the same gender group. The perfect competition model temporarily applied and segmentation of the labour market according to gender diminished.

Within the household, the absence of state welfare was overcome by means of distinctive forms of workers' solidarity. Despite the modernisation of the labour market, the different components of family income reveal the extent to which economic survival was still difficult. The high frequency of complex households together with the presence of lodgers, demonstrates how migrant workers had to supplement their income by expanding their households to enable other economically active persons to contribute to the family economy. We have stressed the major contribution of the work undertaken by migrant married women in bringing into the household collateral relatives. Nevertheless in due course natives began to imitate the residential strategies of migrants. This indicates that the entire working class needed to attract additional sources of income to supplement what could be provided by members of a simple family household. In Sabadell by 1925 migrants were clearly more prosperous than natives because although their earnings were equally stable across the life course, they were better able to expand their households by incorporating additional wage earners. In historical terms our example proves that populations in the past reacted in front of adversity making available the economic 
resources needed to guarantee subsistence. In the absence of welfare, families attracted other economically active members into the household (kin related or not) in order to provide additional sources of income. In economic terms our case study provides an example that proves that the ideas stemming from game theory can be applied to the formation of household income in populations of the $20^{\text {th }}$ century.

\footnotetext{
${ }^{1}$ A first draft of this paper was presented at the conference "Worlds of Wages" at Fondation des Treilles in April 1999. Account has been taken of the points raised during discussions. I would also like to express my appreciation for the further suggestions for revision suggested by Ann Carlos and Dudley Baines. Richard Wall has done a thorough editing work, which has improved the final quality of the paper. His final questions on inconsistencies of the first draft have helped, I guess, to improve the paper in terms of content as well.

${ }^{2}$ For further evidence see session B 17'The microeconomic analysis of the household and the labour market' of the 12th International Economic History Conference (Madrid 1998).

${ }^{3}$ See A.Janssens ,"(1993) and the recent summary of the debate by P. Scholliers, P. Van den Eckout, "The Construction of Women's Paid Labour", Proceedings of the $12^{\text {th }}$ International Economic History Congress, B17, (Madrid 1998). I have emphasised this point in E.Camps-Cura, "Transition in Women's and Children's Work Patterns and Implications for the Study of the Household Structure and the Family Income", The History of the Family. An International Quaterly 3:2 (1998).

4 S.Horrell, J.Humphries, "Women's labour force participation and the transition to the malebreadwinner family, 1790-1865", Economic History Review 48 (1995)

5 See the article by M.R. Haines, "Industrial work and family life cycle, 1889-1890", Research in Economic History, 4 (1979), based on thousands of European and North American family budgets in 1890 and all the case studies that followed. For the British case see also S. Horrell, J.Humphries "Women's Labour Force Participation", S.Horrell, J.Humphries, "The Origins and Expansion of the Male Breadwinner Family: The Case of Nineteenth-Century Britain”, in A.Janssens (ed.) The Rise and Decline of the male Breadwinner Family?, international review of social history, 42 (1997).

${ }^{6}$ P. Vilar, Catalunya dins de l'Espanya Moderna, (Barcelona 1966)

7 See J. Nadal, El fracaso de la revolución industrial en España, 1814-1913, (Barcelona 1975). L. Prados de la Escosura, De imperio a nación. Crecimiento y atraso económico en España (1870-1930), (Madrid, 1988).

${ }^{8}$ T. Hatton and R.V. Baliey, Poverty and the Welfare State in interwar London", Proceedings of the $12^{\text {th }}$ International Congress of Economic History, B17 ( Madrid 1998).

${ }^{9}$ M. Carbonell, Sobreviure a Barcelona. Dones, pobresa i assitència al segle XVIII (Vic, 1997).

${ }^{10}$ Intensity of internal migrations in Catalonia were calculated in Camps (1995). The result is that over the period in consideration 1 out of each $4-5$ rural births definitively migrated to towns. This result is close to evidence shown by De Vries (1985) for the most industrialised regions of Europe.

${ }^{11}$ See D.S.Reher, Town and Country in Pre-industrial Spain, (Cambridge 1991); D.S. Reher and E. Camps Cura "Las economías familiares dentro de un contexto histórico comparado", Revista Española de Investigaciones Sociológicas, 55 (1991) and M. Arbaiza "Labor migration in the First Phase of Basque Industrialisation: The Labor Market and Family Motivations", The History of the Family. An international Quaterly, 3:2, (1998). E. Camps i Cura, "Population Turnover and the Family Cycle. The Migration Flows in a Catalan Town during the $19^{\text {th }}$ Century", Continuity and Change, 7:2, 1992.

12 See E. Camps i Cura "Population Turnover and the Family Cycle". More than half of all migrants had to move through at least three industrial towns before finding a more permanent settlement during the critical phase of the family life cycle.

${ }^{13}$ For the patterns of technological change see J. Nadal, "El fracaso de la revolución"and J.Nadal, J. Maluquer de Motes, Catalunya la fàbrica d'Espanya, (Barcelona 1985).

${ }^{14}$ See S. Pollard, Peaceful Conquest, (Oxford 1981) for the labour savings resulting from the use of capital-intensive techniques in cotton spinning.

${ }^{15}$ Trends in textile employment were first presented in G.Barnusell, E.Camps, A.Garcia, L.Muñoz and J.R. Roses (1994): “Ocupación, productividad y salarios (1850-1913): una reflexión sobre el caso catalán, V Simposio de Análisis Económico, Universitat Autónoma de Barcelona (Bellaterra 1994). All employees (men, women and children) have been included.

${ }^{16}$ The perfect competition model applies when real wages are equal to marginal productivity. It implies the same wage for the same level of skill.

${ }^{17}$ See the syntheses on the literature on implicit contracts in S. Rosen, "Implicit Contracts: A Survey", Journal of Economic Literature, 23 (1985).
} 
${ }^{18}$ We understand that figure 1 represents a small evidence but in historical terms it was the first
showing the relationship between wage profiles and cohorts (Camps 1995). It was impossible to mab the sing the relationship between wage profiles and cohorts (Camps 1995). It was impossible to make followed in these cohorts were fired.

19 See E. Camps, La formación del nercado de trabajo en la Cataluña industrial del siglo XIX, Ministerio de Trabajo y Seguridad Social ( Madrid 1995).

${ }^{20}$ For this topic see S. Rosen "Implicit Contracts"; G.Ferrérol and P. Deubel, Economie du Travail, (Paris 1990); D.Gambier and M.Vernières, Le marché du travail, (Paris 1985) and and historical perpective in M.Huberman, Escape from the Market, (Cambridge 1996).

${ }^{21}$ Nuevo Régimen 18 July 1892.

${ }^{22}$ These internal labour markets were informal in character and were not bureaucratic like the modern internal labour markets of the twentieth century. See E.Camps "La formación del mercado de trabajo", W..Sundstrom, Internal Labour Markets before Word War I.On-the-job Training and Employee promotion", Explorations in Economic History, 25 (1988) and M.Brown and P.Philips, The Historical Origin of Job Ladders in U.S. Canning Industry and their Effects on Gender Division of Labour", Cambridge Journal of Economics (1986).

${ }^{23}$ For further details see E.Camps "La formación del mercado de trabajo industrial".

${ }^{24}$ For the case of Cuenca see D. Reher "Town and Country", and for Mallorca, K. Schürer and I. MollBlanes , "Working lives: rhythms of household income in early twentieth century Mallorca", Tenth International Economic History Congress, (Leuven 1990).

${ }^{25}$ E. Camps, "La formación del mercado de trabajo". Another sign that they lacked property is that there is no mention of any property in the marriage contracts involving wage workers, drawn up by notaries.

${ }^{26}$ In practice the vast majority of persons termed here 'natives' were second and third generation migrants.

27 The accountancy of wages and hours in the archives of the firms leaves little doubt on the transformation of labour relations and labour reward during the period.

${ }^{28}$ T.Hatton, J.G.Williamson, The age of mass migration. Causes and economic impact, (Oxford, 1998).

${ }^{29}$ This is based on evidence for Barcelona in 1764. See Instituto Muncipal d'Historia de Barcelona, Fondo de la Junta de Comercio, vol. 81.

${ }^{30}$ See E. Camps "La formación del Mercado de trabajo". Between 1847 and 1887 the average length of service by women was no more than five years.

${ }^{31}$ C. Goldin, Understanding the Gender Gap: An Economic History of American Women (New York, 1990); C.Goldin, "The U-shaped female labour force function in economic development and economic history" National Bureau of Economic Research, Working Paper Series n.4707 (Cambridge 1994); T. Hatton , R.E. Bailey "Household labour supply and women's work in interwar Britain" Explorations in Economic History, 30 (1993).

${ }^{32}$ E. Camps, "Family Strategies"

${ }^{33}$ In the nineteenth century the majority of women employed in factories were young and unmarried.

${ }^{34}$ E. Camps "Family Strategies".

${ }^{35}$ See T. Hatton, R. Bailey "Poverty and the welfare state" and D. Baines, P. Johnson, "Labour force participation and economic well-being of older men in London, 1929-31" Interntional Congress of Economic History ( Madrid, 1998).

${ }^{36}$ For example C. Lis, Social Change and the Labouring Poor. Antwerp, 1770-1860,(Yale 1986).

37 R. Wall, "The transformations of the European Family across the Centuries", Workshop of Economic History, Pompeu Fabra University (Barcelona 1997). 
Figure 1. Total employment in Catalan cotton textiles.

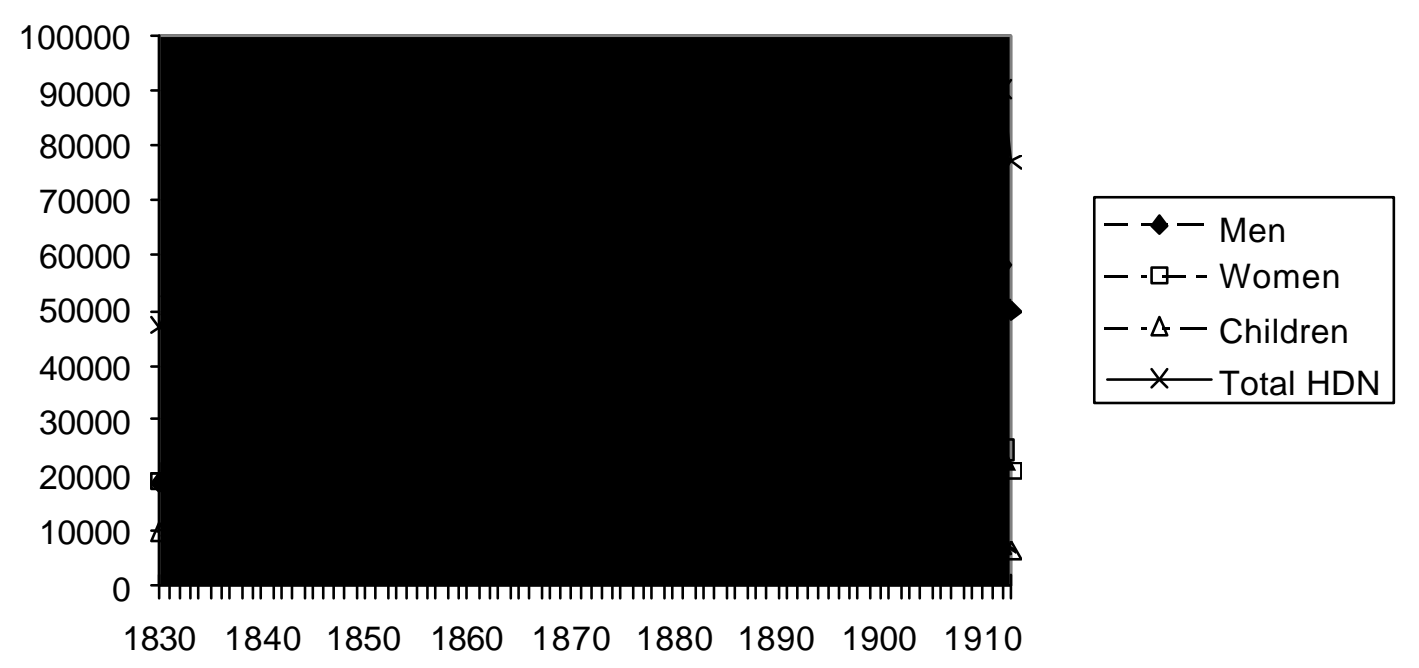

TABLE 1

WAGES ACCORDING TO THE MARRIAGE COHORT

Period of marriage.

\begin{tabular}{lclcccc} 
& N.Obs. Wage & N.Obs & Wage & \multicolumn{2}{c}{ N.Obs. Wage } \\
$1847-51$ & 126 & 13,21 & 148 & 9,62 & 47 & 6,86 \\
$1852-56$ & 213 & 15,67 & 475 & 11,66 & 238 & 8,11 \\
$1857-61$ & 45 & 18,09 & 119 & 13,33 & 83 & 9,40 \\
$1862-66$ & 25 & 19,84 & 69 & 13,72 & 53 & 12,64 \\
$1867-71$ & 20 & 20,11 & 50 & 14,50 & 41 & 14,55 \\
$1872-76$ & 19 & 19,91 & 44 & 15,62 & 48 & 15,62 \\
$1877-81$ & 17 & 20,69 & 44 & 16,36 & 36 & 16,46 \\
$1882-86$ & 12 & 22,81 & 30 & 16,04 & 34 & 17,66
\end{tabular}

Source: Camps (1995). Table made up of the nominal record linkage of the Payrolls of the firm "España Industrial, S.A." and the marriage registers of the Bishopric of Barcelona. 
Figure 2. Wages according to hierarchy and years of service

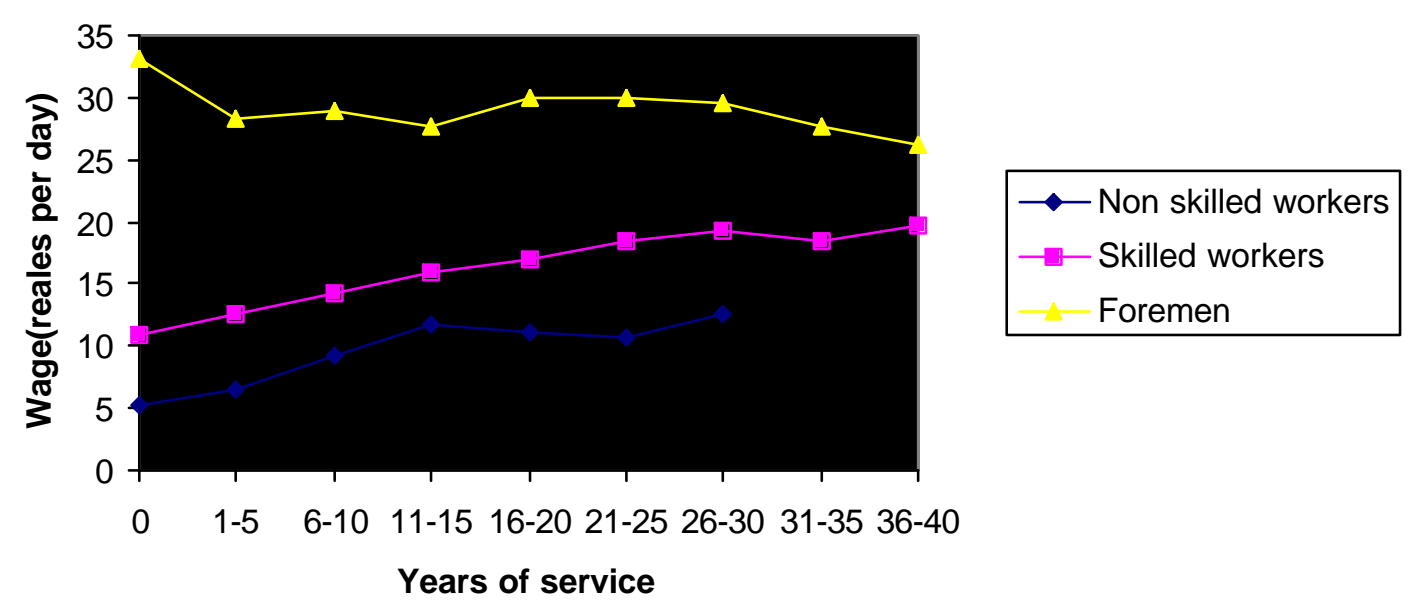

Average wage according to average age of migrant and native men, 1925

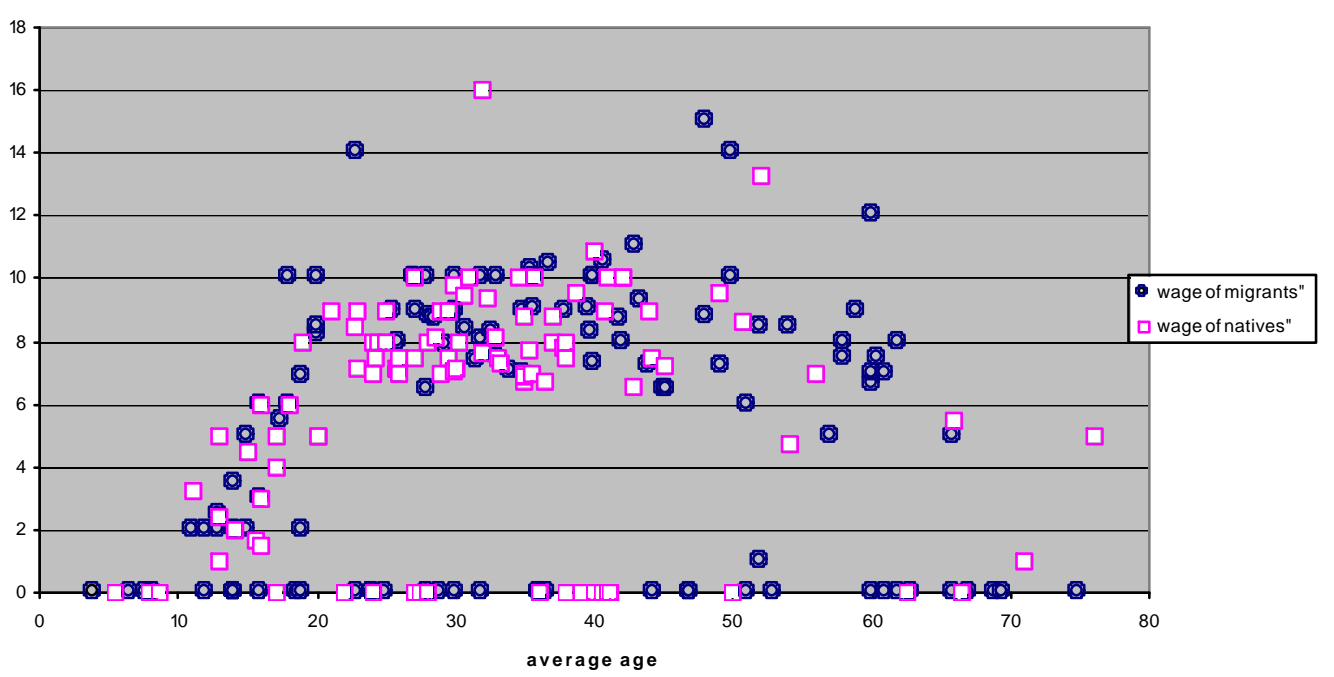


Average age and average wage of migrant and native women, 1925

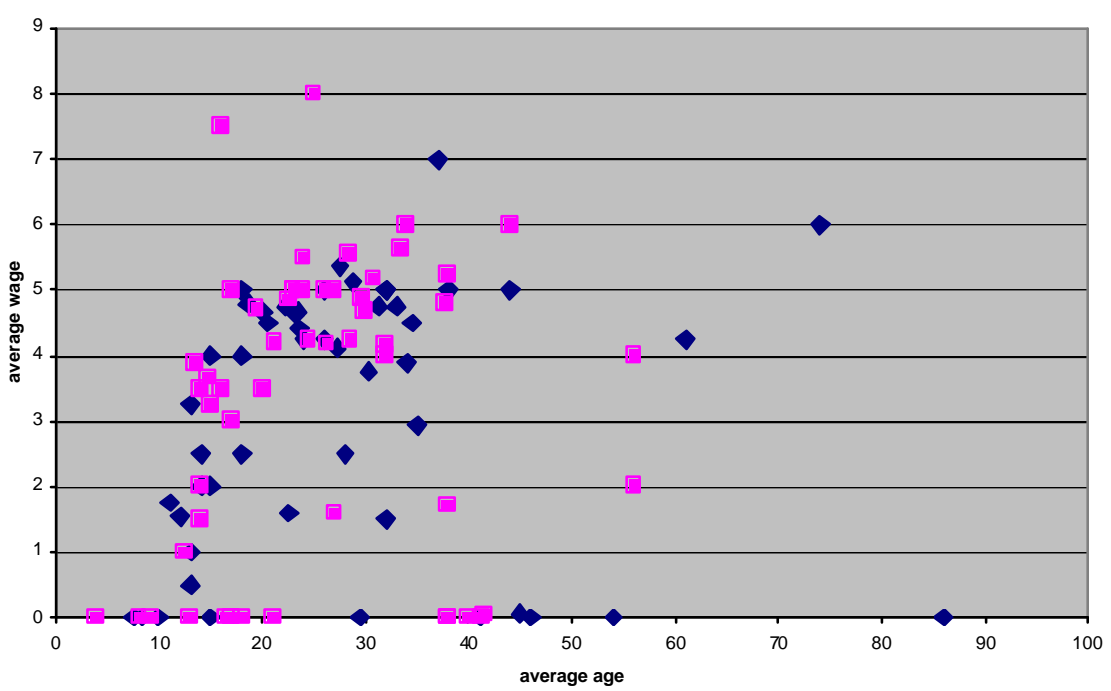

Figure 5: Income structure of the household, 1925

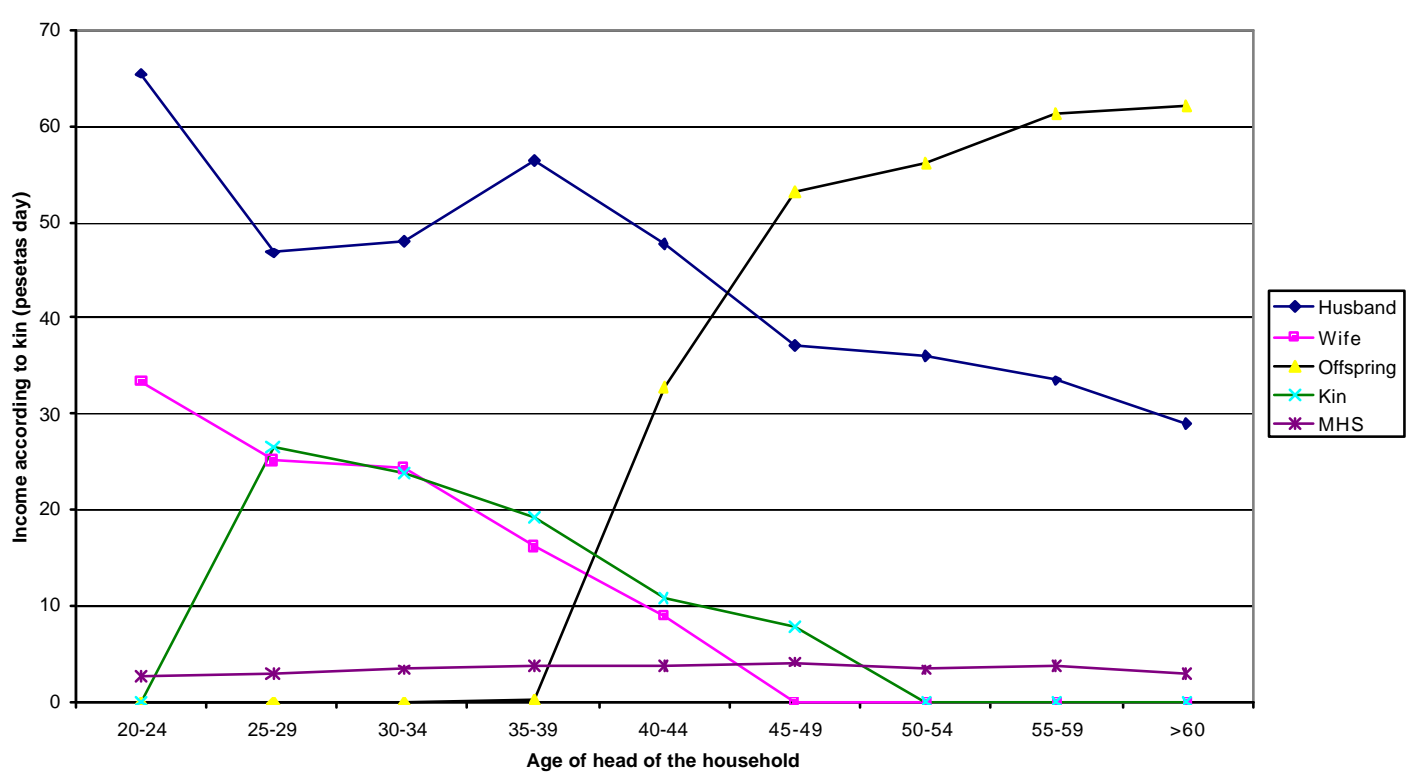


